\title{
The Role of Health Center's Midwives in School Health Programs for Awareness of Breast Self-Examination of High School Students at Semarang District
}

\author{
Peran Bidan Puskesmas dalam Program Kesehatan Sekolah untuk Penyadaran Pemeriksaan \\ Payudara Sendiri (Sadari) pada Siswi-Siswi Sekolah Menengah Atas di Kabupaten Semarang \\ Diana Sundari, Tjahjono Kuntjoro, Resti Nurhayati, V Hadiyono. \\ email: dianasundari94@gmail.com
}

Health Law Master Program, Soegijapranata Catholic University of Semarang

\begin{abstract}
Midwifery service is a service that is inseparable from health care system. Breast cancer does not only attack to old ages but also to adolescence. A midwife is one of the health workers having an important and strategic position as an educator that is to provide health education on breast self-examination (Sadari). The objective of this study was to determine the midwife's role in arising awareness of breast self-examination (Sadari) to high school-aged students.
\end{abstract}

This was a socio-legal study having an analytical descriptive specification. It used first data and secondary data; the primary primary data gathering technique was through interviews to respondents and resource persons. The respondents consisted of midwives and female students at Semarang Regency while the resource persons were Heads of Semarang's Health Centers.

The results showed that the role of midwives in school health programs could be seen in screening and PKPR programs based on the Act Nr. 36 of 2009 on Health, especially Article 79 paragraph (1) and Health Minester's Regulation (Permenkes) Nr. 75 of 2014 on Health Center (Puskesmas), especially Article 36 paragraph (1). The aim of the screening and PKPR programs was to optimally improve the students' health in order to support the learning process. The midwife's role as an implementer and educator in implementing school health programs had been carried out through both programs. The midwife's role as an educator was to provide education and counseling to the students related to adolescent health. The midwife's role in school programs related to awareness of breast self examination had not been implemented optimally because the counseling focused more on adolescent reproductive health. The supporting factors were the availability of health facilities at the Health Centers such as counseling room and the cooperation between the Health Centers and the schools in relation with the implementation of the school health program through the coordination of the teachers handling UKS (School Health Unit) and with technical guidance and the supervising personnels of the Health Centers. The inhibiting factors, on the other hand, were lack of health resources availability such as health workers, funds, and health care facilities.

Keywords: midwife's role, school health services, breast self-examination, high school-aged students. 


\section{PENDAHULUAN}

Kesehatan ialah hak asasi manusia yang menjadi salah satu unsur dari kesejahteraan yang perlu diwujudkan sesuai dengan cita-cita bangsa. Hal ini sebagaimana dimaksud dalam Pancasila dan Undang-Undang Dasar Negara Republik Indonesia Tahun 1945. Berdasarkan Pasal 28H ayat (1) Undang-Undang Dasar Negara Republik Indonesia tahun 1945 (UUD RI 1945) bahwa "setiap orang berhak hidup sejahtera lahir dan batin, bertempat tinggal, dan mendapatkan lingkungan hidup yang baik dan sehat serta berhak memperoleh pelayanan kesehatan". Setiap aktivitas yang dilakukan ialah sebagai upaya demi mencapai derajat kesehatan masyarakat setinggi-tingginya dilaksanakan berdasarkan prinsip nondiskriminatif, partisipatif, perlindungan, dan berkelanjutan yang sangat penting artinya bagi pembentukan kemampuan setiap individu yang ada di Indonesia, peningkatan ketahanan dan daya saing bangsa, serta pembangunan nasional. ${ }^{1}$

Di samping itu kesehatan juga merupakan hal yang sangat penting bagi setiap makhluk hidup secara sosial dan ekonomi. Sehat merupakan suatu keadaan yang terbebas dari berbagai macam penyakit baik secara mental, fisik, dan sosial. Pada pengertian tersebut dapat mewujudkan sehat secara optimal dengan mengupayakan dan meningkatkan derajat kesehatan, mencegah penakit, meyembuhan dan proses pemulihan yang akan dilaksanakan secara menyeluruh, terpadu dan berkesinambungan. Hal tersebut dapat di lihat pada saat melakukan aktivitas fungsional sehari-hari, untuk pengembangan status kesehatan akibat cedera atau kehilangan fungsi tubuh, agar dapat meningkatkan sumber daya manusian maka harus ada penyembuhan dan pemulihan kesehatan.

Puskesmas memiliki fungsi memberikan pelayanan kesehatan dan sebagai penyediaan sarana dan prasarana guna melindungi, menunjang dan meningkatkan kesehatan manusia yang juga menjadi salah satu bentuk perlindungan hukum dalam mendapatkan perhatian hukum. Pelayanan kesehatan sebagai hak dasar untuk meningkatkan derajat kesehatan yang lebih baik untuk setiap manusia berdasarkan pada hak atas pelayanan kesehatan harus dipenuhi oleh negara sebagai pemangku hak asasi manusia melalui realisasi kebijakan terkait penyediaan pelayanan kesehatan sebagai wujud pemenuhan hak setiap warga negara terhadap pelayanan kesehatan.

Tenaga kesehatan merupakan individu yang memiliki kemampuan untuk menjalankan juga memiliki kewenangan dalam bidang kesehatan. Tenaga kesehatan memiliki kewenangan dalam memberikan pelayanan kesehatan kepada pasien baik dalam bentuk upaya promosi kesehatan, pencegahan, pengobatan, dan pemulihan. Berdasarkan Pasal 11 ayat 1 butir d Undang-Undang Nomor 36 Tahun 2014 tentang Tenaga Kesehatan, tenaga kesehatan dikelompokan menjadi beberapa kelompok, salah satunya adalah tenaga kebidanan.Pasal 1 ayat 2 Peraturan Menteri Kesehatan Nomor 28 tahun 2017 tentang Izin dan Penyelenggaraan Praktik Bidandisebutkan bahwa: "Praktik Kebidanan adalah kegiatan pemberian pelayanan yang dilakukan oleh Bidan dalam bentuk asuhan kebidanan."

Fokus upaya pelayanan kebidanan ialah pada promosi kesehatan, pencegahan, juga pertolongan persalinan normal, deteksi komplikasi ibu dan anak, serta pelaksanaan tindakan asuhan sesuai dengan kewenangan atau bantuan jika diperlukan, serta juga melaksanakan tindakan kegawat daruratan. Berkaitan dengan pelayanan di Indonesia, seorang bidan mempunyai tugas yang sangat penting dalam melalukan konseling juga

\footnotetext{
${ }^{1}$ Muchtar Masrudi, 2014, Bidan dan Dinamika Hukum Kesehatan Reproduksi di Indonesia, Yogyakarta: Aswaja Pressindo, Hal 25.
} 
pendidikan kesehatan, yang pula tidak hanya kepada perempuan, namun terhadap keluarga serta masyarakat. Kegiatan yang dilakukan mencakup pendidikan antenatal juga persiapan untuk menjadi orang tua. Selain itu penting pula untuk memberikan pendidikan seputar kesehatan wanita, kesehatan seksual/ kesehatan reproduksi serta asuhan anak.

Untuk mempersiapkan manusia dewasa sehat dan produktif, baik ekonomi maupun social perlu dilakukan upaya pemeliharaan kesehatan remaja termasuk upaya reproduksi remaja perlu dilakukan agar terlepas dari berbagai masalah kesehatan yang dapat menghambat kemampuan dalam menjlani kehidupan reproduksi dengan sehat. Masa remaja adalah suatu periode rentan kehidupan manusia yang sangat kritis karena merupakan tahap transisi dari masa kanak-kanak ke masa dewasa. Pada tahap ini sering kali remaja tidak menyadari bahwa tahap perkembangan sudah dimulai, namun yang pasti setiap remaja akan mengalami suatu perubahan baik fisik, emosional, maupun sosial. Pada wanita, hormonhormon ini bertanggunjawab atas permulaan proses ovulasi dan menstruasi, juga pertumbuhan payudara.

Kanker payudara dapat ditemukan secara dini dengan Pemeriksaan Payudara Sendiri (Sadari), pemeriksaan klinik dan pemeriksaan mammografi. Deteksi ini dapat menekan angka kematian 25-30\%. Pemeriksaan payudara sendiri (sadari atau Breast Self Examination) semua wanita di atas usia 16 tahun sebaiknya melakukan sadari setiap bulan dan segera periksakan diri ke dokter bisa ditemukan benjolan. Sadari sangat mudah dan bisa diakukan sendiri dirumah. Semakin sering memeriksa payudara akan semakin mengenalnya dan semakin mudah menemukan suatu kelainan pada payudara. Tindakan ini sangat penting karena hampir $85 \%$ benjolan payudara ditemukan oleh penderita sendiri. Secara rutin wanita dapat melakukan metode Sadari dengan cara memijat dan meraba seputar payudaranya untuk mengetahui ada atau tidak adanya benjolan disekitar payudara.

Dalam upaya pemeliharaan kesehatan remaja, pemerintah berkewajiban menjamin agar remaja dapat memperoleh edukasi, informasi dan layanan mengenai kesehatan remaja agar mampu hidup sehat dan bertanggung jawab. Ketentuan terkait kewajiban pemerintah untuk menjamin agar remaja mendapatkan informasi, edukasi, dan layanan terkait kesehatan dilaksanakan sesuai pertimbangan berdasarkan ketentuan peraturan perundangundangan dan moral nilai agama. ${ }^{2}$

Penyakit kanker adalah salah satu dari penyebab kematian utama di seluruh dunia. Kanker adalah pertumbuhan yang tidak normal dari sel-sel jaringan tubuh yang berubah menjadi ganas. Sel-sel tersebut dapat tumbuh lebih lanjut serta menyebar ke bagian tubuh lainnya serta menyebabkan kematian. Sel tubuh yang mengalami mutasi (perubahan) dan mulai tumbuh dan membelah lebih cepat dan tidak terkendali seperti sel normal. Sel kanker tidak mati setelah usianya cukup melainkan tumbuh terus dan bersifat invasif sehingga sel normal tumbuh dapat terdesak atau malah mati.

Saat ini, salah satu jenis penyakit kanker yaitu kanker payudara menjadi jenis kanker yang sangat menakutkan bagi perempuan di seluruh dunia, juga di Indonesia. Kanker payudara adalah tumor ganas yang terbentuk dari sel-sel payudara yang tumbuh dan berkembang tanpa terkendali sehingga dapat menyebar di antara jaringan atau organ di dekat payudara atau ke bagian tubuh lainnya.

${ }^{2}$ Notoatmodjo Soekidjo, 2010, Etika dan Hukum Kesehatan, Jakarta: Rineka Cipta, Hal 68. 
Pemerintah Indonesia dalam upaya penanggulangan kanker, sudah melaksanakan secara khusus program deteksi dini kanker pada perempuan Indonesia untuk kanker Leher rahim dan kanker payudara. Program tersebut mulai berjalan sejak tahun 2008 dengan dilakukannya "Pencanangan Program Nasional Deteksi Dini Kanker Leher Rahim dan Kanker Payudara" pada april 2008 oleh ibu negara Hj. Ani Bambang Yudhoyono dan diperkuat dengan "Pencanangan Peran serta Masyarakat dalam Pencegahan dan Deteksi Dini Kanker pada Perempuan Indonesia" oleh ibu Negara Hj. Iriana Joko Widodo pada april deteksi dini kanker payudara dengan Pemeriksaan Payudara Klinis (Sadanis) dan kanker leher rahim dengan metode Inspeksi Visual dengan Asam Asetat (IVA). Berkat dukungan tersebut, periksa Sadanis dan IVA yang dilaporkan sampai dengan tahun 2016 menunjukkan peningkatan yang signifikan (57\%) menjadi 1.623 .913 orang dari 904.099 orang pada akhir tahun 2014.

Kabupaten Semarang adalah salah satu kabupaten otonom di Provinsi Jawa Tengah. Secara administratif wilayah Kabupaten Semarang Terdiri dari 19 Kecamatan yang terdiri dari 208 desa dan 27 Kelurahan. Adapun jumlah Puskesmas pada Kabupaten Semarang berjumlah 26 Puskesmas. Puskesmas yang menjadi lokasi penelitian yaitu Puskesmas Ungaran, Pringapus, Jimbaran, Somowono dan Kaliwungu. Berdasarkan wawancara awal pada beberapa siswa SMA mengatakan masih jarang dilakukan penyuluhan terkait Sadari.

Dari data Dinas Kesehatan Provinsi Jawa Tegah selama 5 tahun terakhir terdapat jumlah penderita Kanker Payudara dengan Pemeriksaan Klinis (CBE). ${ }^{3}$

Tabel 1.

Data Jumlah Penderita Kanker Payudara di Kabupaten Semarang

\begin{tabular}{|c|c|}
\hline Tahun & $\begin{array}{c}\text { Cakupan Deteksi Dini Kanker Leher Rahim dan } \\
\text { Kanker Payudara di Kabupaten Semarang }\end{array}$ \\
\hline 2012 & 134 \\
\hline 2013 & 102 \\
\hline 2014 & 89 \\
\hline 2015 & 23 \\
\hline 2016 & 150 \\
\hline
\end{tabular}

Sumber: Profil Dinas Kesehatan Provinsi Jawa Tengah tahun 2012-2015.

American Cancer Society (ACS/2011) menganjurkan bahwa sadari perlu dilakukan oleh wanita usia dua puluh tahun atau lebih setiap bulannya yaitu pada hari ke-7 atau ke-10 setelah selesai haid. Namun seiring berjalan waktu, penyakit ini mulai mengarah ke usia lebihmuda, maka usia remaja (13-20 tahun) juga perlu untuk melakukan Sadarisecara rutin sebagai upaya pencegahan dan deteksi dini.

Saat ini telah banyak ditemukan penderita kanker payudara pada usia muda, bahwa tidak sedikit remaja putri usia empat belas tahun menderita tumor di payudaranya. Dimana tumor tersebut terjadi bisa menjadi kanker, bila tidak terdeteksi lebih awal. Meskipun tidak

\footnotetext{
${ }^{3}$ Dinas Kesehatan Provinsi Jawa Tengah 2012-2015.
} 
semuanya ganas, tetapi hal ini menunjukkan bahwa saat ini sudah ada tren gejala kanker payudara yang semakin tinggi di usia remaja.

Pemahaman remaja terhadap kesehatan reproduksi merupakan modal remaja dalam beperilaku sehat dan bertanggung jawab, akan tetapi tidak semua remaja mendapatkan informasi yang baik terhadap kesehatan reproduksi. Keterbatasan pengetahuan serta pemahaman ini membuat remaja ke arah perilaku beresiko. Sekolah menjadi tempat untuk mendapatkan pendidikan kesehatan, bimbingan, dan dukungan terkait informasi akan kesehatan reproduksi. Usaha Kesehatan Sekolah (UKS) sebagai wadah untuk meningkatkan kemampuan hidup sehat pesera didik sedini mungkin. Dalam wadah UKS terdapat pelayanan kesehatan melalui upaya peningkatan (promotif), pencegahan (preventif), pengobatan (kuratif) dan pemulihan (rehabilitatif).

Seiring dengan perubahan gaya hidup dan perubahan kondisi lingkungan, kemungkinan besar kanker payudara menyerang usia muda (<22 tahun).Berdasarkan data yang dihimpun oleh Bagian Onkologi FK UNUD, RSUP Sanglah, pada bulan Januari 2007- April 2012, terdapat lima orang remaja yang berusia 13-22 tahun menderita tumor ganas payudara. Hal ini menunjukan bahwa pada usia remaja, gejala kanker payudara semakin meningkat kasusnya. Salah satu cara untuk meningkatkan kesadaran remaja menurunkan kejadian distant yaitu dengan meningkatkan pengetahuan, sikap dan perilaku remaja putri tentang deteksi dini kanker payudara. Diperkirakan 95\% perempuan yang terdiagnosis pada tahap pertama kanker payudara dapat bertahan hidup lebih dari 5 tahun setelah diagnosis dan dapat menurunkan angka kematian yaitu sebesar 25-30\%, sehingga para dokter yang menganjurkan supaya para perempuan menjalani Sadari.

Wanita yang melakukan deteksi dini kanker payudara dapat dikatakan masih sedikit. Padahal pentingnya memeriksakan payudara sejak dini adalah untuk mengetahui payudara seorang wanita dalam keadaan normal atau tidak. Permasalahan yang terjadi adalah penanganan kanker di Indonesia masih kurang optimal, karena hampir 70\% kasus baru ditemukan dalam stadium tiga dan stadium empat.Kesembuhan kanker ditentukan oleh kondisi kanker payudara saat pertama kali ditemukan. Kanker yang ditemukan pada stadium I kemungkinan kesembuhan mencapai 80-90\%. Pada stadium II di mana kanker mulai menjalar ke kelenjar limfa di sekitar payudara, kemungkinan kesembuhan menurun menjadi $60-70 \%$. Kemungkinan kesembuhan semakin menurun padapenderita stadium III yaitu $30-40 \%$. Keadaan terburuk pada stadium IV dengan kemungkinan kesembuhan kurang dari $10 \%{ }^{4}$

Latar belakang pemikiran yang mendasari tingginya angka penderita kanker payudara maka Sadari merupakan upaya deteksi dini atau pencegahan kanker payudara yaitu dengan melakukanSadari. Sadari adalah tindakan deteksi dini terhadap adanya gejala-gejala kanker payudara. Metode ini sangat mudah dan sederhana, namun diharapkan dapat menekan tingginya angka penderita kanker payudara, karena semakin awal terdeteksi maka semakin cepat proses pengobatan yang diperlukan. Sadari dianjurkan pada wanita, terutama pada wanita dengan usia mulai dari 16 tahun. Karena wanita dengan usia subur 16-45 tahun sangat berisiko terkena penyakit kanker payudara, sehingga wanita harus selalu sadar akan kesehatan payudaranya yaitu dengan cara rutin memeriksa payudaranya sebagai upaya

${ }^{4}$ Rahmatari Aida, Anggapan Kesehatan Yang Dirasakan Wanita Usia Subur Dalam Memeriksakan Payudara Sejak Dini, Universitas Airlangga. Volume 2, No 3, September 2014. Hal309-320. https://ejournal.unair.ac.id/JBE/article/viewFile/1298/1057diakses tanggal 23 maret 2018 jam 20.15 WIB. 
awal pencegahan penyakit kanker payudara. Cukup dimulai dengan cara yang paling mudah dan sederhana yang dapat dilakukan sendiri di rumah dan dilakukan setiap seminggu setelah selesai masa menstruasi yakni dengan Sadari.

Berdasarkan latar belakang di atas maka pada kesempatan ini penulis berkeinginan untuk melaksanakan penilitian dengan judul "Peran Bidan Puskesmas dalam Program Kesehatan Sekolah untuk Penyadaran Pemeriksaan Payudara Sendiri (Sadari) pada Siswi-Siswi Sekolah Menengah Atas di Kabupaten Semarang".

\section{PERUMUSAN MASALAH}

Berdasarkan uraian dari latar belakang masalah tersebut di atas, dapat dirumuskan permasalahan sebagai berikut:

1. Bagaimana implementasi Pasal 79 ayat (1) UU Nomer 36 tahun 2009 tentang kesehatan sekolahuntuk penyadaran pemeriksaan payudara sendiri (Sadari)pada siswi-siswi Sekolah Menengah Atas di Kabupaten Semarang?

2. Bagaimana peran bidan puskesmas dalam program kesehatan sekolah untuk penyadaran pemeriksaan payudara sendiri (Sadari) pada siswi-siswi Sekolah Menengah Atas di Kabupaten Semarang?

3. Faktor-faktor apa yang mendukung dan menghambat peran bidan puskesmas dalam program kesehatan sekolah untuk penyadaran pemeriksaan payudara sendiri (Sadari) pada siswi-siswi Sekolah Menengah Atas di Kabupaten Semarang?

\section{METODE PENELITIAN}

1. Metode Pendekatan menggunakan metode pendekatan yuridis sosiologis, yang merupakan pendekatan hukum yang berlaku dalam masyarakat.

2. Spesifikasi yang digunakan pada penelitian ini adalah penelitian deskriptif analitik. ${ }^{5}$

3. Definisi Operasional

Adapun variabel yang akan diteliti terdiri dari dua variabel yaitu variabel dependen (terikat) dan variabel independen (bebas). Adapun variabel dependen yaitu:

1. Peran

Peran adalah suatu tindakan atau aktifitas yang diharapkan oleh masyarakat atau pihak lainnya untuk dilakukan oleh seseorang sesuai dengan status yang mereka miliki. Peran bidan dalam hal ini sebagai edukator yaitu dengan memberikan penyuluhan-penyuluhan kesehatan tentang penyadaran pemeriksaan payudara sendiri (Sadari).

2. Bidan

Bidan adalah seorang perempuan yang telah menyelesaikan program pendidikan kebidanan yang di akui secara sah oleh pemerintah pusat dan telah memenuhi persyaratan untuk melakukan praktik kebidanan.

\footnotetext{
${ }^{5}$ Bambang Sunggono, 2007, Metode Penelitian Hukum, Jakarta Rajagrafindo Persada, Hal. 35.
} 
3. Puskesmas

Puskesmas bertanggung jawab dalam menyelenggarakan pembangunan kesehatan, fungsi sebagai pusat pembangunan kesehatan masyarakat. fungsi Puskesmas sebagai ujung tombak pembangunan bidang kesehatan.

Adapun variabel Independen yaitu:

1. Sadari

pemeriksaan payudara sendiri yang bertujuan untuk mengetahui ada tidaknya kanker dalam payudara wanita.

2. Kesehatan Sekolah

Merupakan salah satu usaha kesehatan pokok yang dilaksanakan oleh puskesmas dan usaha kesehatan masyarakat yang dijalankan di sekolah-sekolah dengan anak didik serta lingkungan sekolahnya sebagai sasaran utama.

3. Usia Sekolah Menengah Atas

Merupakan periode masa transisi dari masa anak ke masa dewasa yang ditandai dengan percepatan perkembangan fisik, mental, emosional dan sosial.

4. Subyek dan Obyek Penelitian

a. Subjek: Bidan dan Siswi.

b. Objek: Puskesmas.

5. Jenis Data

Jenis data yang digunakan dalam penelitian ini adalah data primer dan data sekunder. Data primer adalah data yang diperoleh dari hasil penelitian langsung di masyarakat (hasil wawancara terhadap responden dan narasumber), sedangkan data sekunder adalah data yang diperoleh dari hasil penelaahan terhadap berbagai literatur atau bahan pustaka yang berkaitan dengan masalah atau materi penelitian. ${ }^{6}$

6. Metode Pengumpulan Data

Penelitian ini menggunakan teknik pengumpulan data wawancara mendalam, ditandai dengan penggalian mendalam tentang segala sesuatu tentang masalah penelitian dengan menggunakan pertanyaan terbuka. Sampel yang dipilih dari populasi sesuai dengan kehendak peneliti dengan pertimbangan atau kriteria tertentu (purposive sampling). ${ }^{7}$

7. Metode Analisis Data dalam penelitian ini menggunakan analisa data kualitatif. ${ }^{8}$

\section{PEMBAHASAN}

\section{Gambaran Umum Lokasi Penelitan}

Penelitian ini dilakukan di Wilayah Kerja Puskesmas di Kabupaten Semarang. Kabupaten Semarang adalah salah satu kabupaten otonom di Provinsi JawaTengah. Secara administratif wilayah Kabupaten Semarang Terdiri dari 19 Kecamatan yang terdiri dari 208 desa dan 27 Kelurahan. Terletak pada posisi $110^{\circ} 14^{\prime} 54,74^{\prime \prime}-110^{\circ} 39^{\prime} 3^{\prime \prime}$ BJ dan 70 3' 57" 70 30'0" LS. Kabupaten semarang memiliki luas wilayah adalah 95.020,674 Ha atau 2,92\%

\footnotetext{
${ }^{6}$ Ronny Hanitijo S, 1990, Metodologi Penelitian Hukum dan Jurimetri, Jakarta: Ghalia Indonesia, Hal 53.

${ }^{7}$ Ibid., Hal 51.

${ }^{8}$ Ghony Djunaidi dan Fauzan Almanshur, 2014, Metode Penelitian Kualitatif, Yogyakarta: Ar-Ruzz Media, Hal 246.
} 
dari luas wilayah Provinsi Jateng. Jumlah Puskesmas pada Kabupaten Semarang berdasarkan data dari Dinas Kesehatan Kabupaten Semarang berjumlah 26 Puskesmas.

Puskesmas yang menjadi lokasi penelitian yaitu Puskesmas Ungaran, Pringapus, Duren, Somowono dan Kaliwungu. Sekolah yang menjadi lokasi penelitian adalah SMA Negeri 1 Ungaran, MA Darul Ma'arif, SMK Theresiana, SMA Sumowono dan SMK Kaliwungu. Adapun batas-batas wilayah KabupatenSemarang sebagai berikut:

a. Sebelah utara berbatasan langsung dengan kabupaten demak dan Kota Semarang.

b. Sebelah timur berbatasan langsung dengan KabupatenBoyolali dan Kabupaten Grobogan.

c. Sebelah selatan berbatasan langsung dengan KabupatenMagelang dan KabupatenBoyolali

d. Sebelah barat berbatasan langsung dengan kabupaten Kendal dan KabupatenMagelang. ${ }^{9}$

Implementasi Pasal 79 ayat (1) UU Nomer 36 tahun 2009 tentang Kesehatan Sekolah untuk Penyadaran Pemeriksaan Payudara Sendiri (Sadari) pada Siswi-siswi Sekolah Menengah Atas di Kabupaten Semarang

Berdasarkan PERMENKES NO 75 tahun 2014 defenisi Pusat kesehatan masyarakat atau puskesmas adalah fasilitas pelayanan kesehatan yang menyelenggarakan upaya kesehatan masyarakat dan upaya kesehatan perorangan tingkat pertama. Puskesmas merupakan unit organisasi pelayanan kesehatan terdepan dengan misi sebagai pusat pengembangan pelayanan kesehatan, tugasnya adalah melaksanakan pembinaan, pelayanan kesehatan secara menyeluruh, dan terpadu kepada masyarakat disuatu wilayah tertentu. Puskesmas bertanggung jawab dalam menyelenggarakan pembangunan kesehatan disatu atau disebagian wilayah kecamatan yang mempunyai fungsi sebagai pusat pembangunan kesehatan masyarakat, pusat pemberdayaan masyarakat, dan pusat pelayanan kesehatan tingkat pertama dalam rangka pencapaian keberhasilan fungsi Puskesmas sebagai ujung tombak pembangunan bidang kesehatan. ${ }^{10}$

Terkait program kesehatan sekolah diatur pada Pasal 36 ayat (4) Peraturan Menteri Kesehatan termasuk dalam upaya kesehatan pengembangan, upaya pengembangan ini bersifat tidak wajib, yang kegiatannya membutuhkan upaya yang sifatnya ekstensifikasi dan intensifikasi pelayanan. Hasil wawancara terhadap dari kelima Puskesmas terkait pelaksanaan program kesehatan sekolah pada hasil wawancara semua puskesmas melaksanakan program kesehatan sekolah tersebut..1 Namun dalam pelaksanaan di lapangan belum berjalan secara optimal tentang pentingnya penyadaran periksa payudara sendiri.

Terdapat beberapa program kesehatan sekolah yang dilaksanakan setiap Puskesmas yaitu Program Penjaringan dan Program PKPR. Tujuan Program Penjaringan ini yaitu untuk meningkatkan derajat kesehatan peserta didik secara opimal dalam mendukung proses belajar di sekolah. Jadi kegiatan penjaringan ini merupakan pemeriksaan secara berkala melalui wadah Usaha Kesehatan Sekolah (UKS). Program lainnya yaitu Program Pelayanan Kesehatan Peduli Remaja (PKPR). Tujuan dari Program PKPR yaitu meningkatkan

\footnotetext{
${ }^{9}$ Profil Kesehatan Kabupaten Semarang 2018.

${ }^{10}$ Alamsyah Dedi, 2012, Manajemen Pelayanan Kesehatan. Yogyakarta: Nuha Medika, Hal 44.

${ }^{11}$ Hasil wawancara 5 puskesmas di Kabupaten Semarang, pada tanggal 9 September 2018.
} 
penyediaan pelayanan kesehatan remaja yang berkualitas, meningkatkan pengetahuan dan keterampilan remaja dalam pencegahan masalah kesehatan dan meningkatkan keterlibatan remaja dalam perencanaan, pelaksanaan dan evaluasi pelayanan kesehatan remaja.

Pada Peraturan Menteri Kesehatan Republik Indonesia Nomor 43 Tahun 2016 tentang Standar Pelayanan Minimal Bidang Kesehatan pada Pasal 2 ayat (2 F) dikatakan bahwa: "Setiap warga negara Indonesia usia 15 s.d. 59 tahun mendapatkan skrining kesehatan sesuai standar". Pasal ini berfokus terhadap pelayanan kesehatan pada usia produktif dengan standar skrining pada usia produktif.

Kesehatan reproduksi secara umum menunjuk pada kondisi kesejahteraan fisik, mental, dan sosial secara utuh dalam segala urusan yang berhubungan dengan sistem, fungsi, dan proses reproduksi, termasuk hak dan kebebasan untuk bereproduksi secara aman, efektif, tepat, terjangkau dan tidak melawan hukum. Adapun hak reproduksi mencakup hal-hal sebagaiberikut ini : $:^{12}$

a. Hak untuk mendapatkan pendidikan dan informasi terkait kesehatan reproduksi.

b. Hak mendapatkan perlindungan dan pelayanan kesehatan reproduksi.

c. Hak atas membuat keputusan dan kebebasan berpikir tentang kesehatan reproduksi.

Pemerintah mempunyai tanggung jawab untuk menjamin setiap warga negara agar memperoleh pelayanan kesehatan yang berkualitas sesuai dengan kebutuhan termasuk pelayanan kesehatan reproduksi terhadap remaja. Berdasarkan hasil penelitian di beberapa puskesmas bidan pemegang program kesehatan sekolah sudah memberikan pelayanan sesuai standar pelayanan minimal. Namun dalam setiap pelayanan kesehatan yang diberikan belum optimal, dikarenakan pelaksanaan penyuluhan tentang pentingnya penyadaran sadari belum dilaksanakan oleh semua puskesmas sehingga diharapkan kepada Puskesmas untuk mampu meningkatkan kualitas pelayanan tersebut sehingga meciptakan pelayanan kesehatan yang memuaskan bagi remaja/peserta didik yang mendapatkan pelayanan kesehatan.

Puskesmas berdasarkan fungsinya bertanggung jawab menyelenggarakan upaya kesehatan perorangan dan upaya kesehatan masyarakat dalam rangka mewujudkan derajat kesehatan masyarakat yang setinggi-tingginya. Puskesmas dalam menyelenggarakan pelayanan kesehatan memiliki program pokok dan juga program pengembangan sebagaimana diatur dalam Permenkes No 75 Tahun 2014 pada Pasal 36 ayat (2) yang dilaksanakan sesuai kemampuan tenaga dan kelengkapan fasilitasnya. Program puskesmas yang lazim dan seharusnya dilaksanakan adalah sebagai berikut:

1. Promosi Kesehatan;

2. Kesehatan Lingkungan;

3. Kesehatan Ibu dan Anak (KIA);

4. Perbaikan Gizi Masyarakat;

5. Pemberantasan Penyakit Menular (P2M);

\footnotetext{
${ }^{12}$ Intan Kumalasari dan Iwan Andhyantoro, , 2013, Kesehatan Reproduksi untuk Mahasiswa Kebidanan dan Keperawatan, Jakarta: Salemba Medika, Hal. 3.
} 
6. Pengobatan.

Pada program pengembangan beberapa kegiatan yang dilaksanakan yaitu:

a) Upaya kesehatan sekolah;

b) Upaya kesehatan olah raga;

c) Upaya perawatan kesehatan masyarakat;

d) Upaya kesehatan kerja;

e) Upaya kesehatan gigi dan mulut;

f) Upaya kesehatan jiwa;

g) Upaya kesehatan mata;

h) Upaya kesehatan usia lanjut;

i) Upaya pembinaan pengobatan tradisonal.

Upaya kesehatan pengembangan Puskesmas dapat pula berupa upaya inovatif, yakni upaya di luar upaya-upaya tersebut di atas, yang sesuai dengan kebutuhan masyarakat.

Berdasarkan uraian di atas dapat di ambil simpulan bahwa implementasi Pasal 79 ayat (1) tentang kesehatan sekolah pada siswi-siswi sekolah menengah atas di Kabupaten Semarang telah dilaksanakan melalui Program Penjaringan dan Program PKPR. Akan tetapi dalam pelaksanaan di lapangan belum berjalan optimal karena hanya beberapa puskesmas yang melaksanakan penyuluhan tentang kanker payudara dan Sadari tersebut.

Berikut ini terdapat beberapa gambar atau kondisi tempat penelitian di Puskesmas Kabupaten Semarang dan kegiatan tentang kesehatan sekolah, antara lain:

a. Puskesmas Pringapus

Petugas kesehatan di Puskesmas Pringapus melaksanakan pelayanan kesehatan sekolah dalam Program Penjaringan salah satunya yaitu pemeriksaan HB dan pemberian tablet $\mathrm{Fe}$, kegiatan ini dilakukan setiap 6 bulan sekali dan dilakukan monitoring/evaluasi setiap 3 bulan. Selain kegaiatan pemeriksaan HB bidan puskesmas juga memberikan penyuluhan terkait kesehatan reproduksi remaja seperti penyuluhan tentang sistem reproduksi, untuk penyuluhan tentang kanker payudara dan Sadari belum dilaksanakan.

b. Puskesmas Ungaran

Program kesehatan sekolah yang dilaksanakan oleh bidandi Puskesmas Ungaran pada Program Penjaringan salah satunya pemeriksaan tinggi dan berat badan, pemeriksaan gigi dan mulut, pemeriksaan THT, pemeriksaan mata. Kegiatan seperti pemeriksaan gigi yang dilakukan oleh pihak puskesmas Ungaran untuk memeriksa keadaan gigi, apakah terdapat cariesatau tidak. Untuk kegiatan penyuluhan bidan memberikan penyuluhan tentang alat reproduksi dan bahaya seks bebas, untuk penyuluhan tentang kanker payudara dan Sadari belum dilaksanakan.

c. Puskesmas Kaliwungu

Program kesehatan yang dilaksanakan oleh bidan di Puskesmas Kaliwungu pada Program Penjaringan yaitu pemeriksaan gigi dan mulut untu memeriksa apakah terdapat caries pada gigi siswa-siswi. Untuk kegiatan penyuluhan bidan lebih berfokus pada 
penyuluhan tentang kesehatan reproduksi remaja, untuk penyuluhan tentang kanker payudara dan Sadari belum dilaksanakan.

d. Puskesmas Duren

Program kesehatan sekolah yang dilaksanakan oleh bidan di Puskesmas Duren terkait Program Penjaringan yaitu pemberian imunisasi Measle-Rubella (MR). Adapun untuk penyuluhan yaitu tentang sistem reproduksi remaja meliputi penyuluhan tentang penyakit HIV/AIDS, penyakit menular seksual dan beberapa penyakit yang berhubungan dengan sistem reproduksi. Selain penyuluhan tentang sistem reproduksi bidan juga memberikan penyuluhan terkait penyakit kanker payudara pada peserta didik perempuan.

e. Puskesmas Sumowono

Program kesehatan sekolahyang dilaksanakan oleh bidan di Puskesmas Sumowono pada Program Penjaringan salah satunya pemeriksaan tinggi dan berat badan, pemeriksaan gigi dan mulut, pemeriksaan THT, pemeriksaan mata. Penyuluhan tentang penyalahgunaan NAPZA diberikan oleh pihak Polsek setempat, kegiatan tersebut bentuk dari kerja sama dengan pihak puskesmas, untuk penyuluhan tentang kanker payudara dan Sadari belum dilaksanakan.

Dengan sudah terlaksanannya kedua program tersebut sesuai dengan Peraturan Menteri Kesehatan Republik Indonesia Nomor 43 Tahun 2016 tentang Standar Pelayanan Minimal Bidang Kesehatan pada Pasal 2 ayat (2 F) dikatakan bahwa:

"Setiap warga negara Indonesia usia 15 s.d. 59 tahun mendapatkan skrining kesehatan sesuai standar". Pasal ini berfokus terhadap pelayanan kesehatan pada usia produktif dengan standar skrining pada usia produktif."

Dengan demikian dapat di ambil simpulan bahwa puskesmas telah melaksanakan kewajiban dalam pemenuhan hak-hak reproduksi remaja/siswi seperti: hak untuk mendapatkan informasi dan pendidikan kesehatan reproduksi, hak mendapatkan pelayanan dan perlindungan kesehatan reproduksi, dan hak atas kebebasan berpikir dan membuat keputusan tentang kesehatan reproduksi.

\section{Peran Bidan Puskesmas dalam Program Kesehatan Sekolah untuk Penyadaran Pemeriksaan Payudara Sendiri (Sadari) pada Siswi-siswi Sekolah Menengah Atas di Kabupaten Semarang}

Peran bidan dalam pelayanan kesehatan sekolah yaitu berdasarkan kewajiban yang diatur dalam perundang-undangan dan berkaitan dengan sasaran dalam memberikan pelayanan kesehatan.Peran bidan sebagai tenaga professional adalah sebagai pengelola, pelaksana, pendidik dan peneliti. Profesi kebidanan dalam dimensi Undang-undang No.36 tahun 2009 tentang Kesehatan merupakan salah satu tenaga kesehatan di Indonesia. Menurut Undangundang Kesehatan, tenaga kesehatan adalah setiap orang yang mengabdikan diri dalam bidang kesehatan memiliki pengetahuan dan/atau ketrampilan melalui pendidikan di bidang kesehatan yang untuk jenis tertentu memerlukan kewenangan untuk melakukan upaya kesehatan. Profesi kebidanan sebagai tenaga kesehatan di Indonesia tentunya mempunyai kewajiban untuk memberikan pelayanan kesehatan kepada masyarakat yang bersifat promotif, preventif, dan kuratif. Berikut ini adalah tabel yang menjelaskan peran bidan dalam program kesehatan sekolah pada setiap puskesmas yang menjadi lokasi penelitian. 
Tabel 2.

Peran Bidan Puskesmas

\begin{tabular}{|c|c|c|}
\hline No & Puskesmas & Peran Bidan \\
\hline 1. & $\begin{array}{l}\text { Puskesmas } \\
\text { Pringapus }\end{array}$ & $\begin{array}{l}\text { Peran bidan dalam kesehatan sekolah yang dilaksanakan oleh Puskesmas } \\
\text { Pringapus meliputi Program Penjaringan dan Program PKPR. Program } \\
\text { Penjaringan ini dilaksanakan setiap tahun ajaran baru dengan sasaran peserta } \\
\text { didik kelas 1 SD, kelas } 7 \text { SMP, dan kelas } 10 \text { SMA. Pada Program PKPR,kegiatan } \\
\text { yang dilaksanakan yaitu berupa kegiatan penyuluhan. Kegiatan penyuluhan } \\
\text { yang diberikan lebih berfokus pada kesehatan reproduksi, sehingga } \\
\text { penyuluhan terkait pentingnya penyadaran periksa payudara sendiri (Sadari) } \\
\text { belum dilaksanakan. }\end{array}$ \\
\hline 2. & $\begin{array}{l}\text { Puskesmas } \\
\text { Ungaran }\end{array}$ & $\begin{array}{l}\text { Penyelenggaraan kesehatan sekolah termasuk pada upaya pengembangan. } \\
\text { Salah satu kegiatan dalam upaya pengembangan yaitu kegiatan Usaha } \\
\text { Kesehatan Sekolah (UKS). Peran bidan dalam pelaksanaan kesehatan sekolah } \\
\text { dengan melaksanakan Program Penjaringan dan Program PKPR. Pada } \\
\text { Program Penjaringan kegiatan yang dilakukan meliputi pemeriksaan gigi dan } \\
\text { mulut, pemeriksaan mata, pemeriksaan THT, dan pengukuran tinggi dan berat } \\
\text { badan. Sedangkan pada Program PKPR kegiatan yang dilakukan yaitu } \\
\text { penyuluhan. Penyuluhan terkait kanker payudara dan Sadari belum } \\
\text { dilaksanakan karena tidak menjadi program wajib dalam kegiatan penyuluhan. }\end{array}$ \\
\hline 3. & $\begin{array}{l}\text { Puskesmas } \\
\text { Kaliwungu }\end{array}$ & $\begin{array}{l}\text { Kesehatan sekolah merupakan salah satu kegiatan dalam upaya } \\
\text { pengembangan yang diselenggarakan puskesmas. Peran bidan dalam } \\
\text { kesehatan sekolah yaitu pada pelaksanaan Program Penjaringan dan Program } \\
\text { PKPR. Pada Program Penjaringan salah satu kegiatan yang dilakukan yaitu } \\
\text { penyuluhan. Penyuluhan yang diberikan meliputi kesehatan reproduksi seperti } \\
\text { penyuluhan HIV/AIDS, bahaya narkoba, infeksi menular seksual dan lain-lain. } \\
\text { Penyuluhan tentang kanker payudara dan sadari belum dilaksanakan. }\end{array}$ \\
\hline 4. & $\begin{array}{l}\text { Puskesmas } \\
\text { Duren }\end{array}$ & $\begin{array}{l}\text { Beberapa kegiatan kesehatan sekolah yang dilaksanakan oleh puskesmas } \\
\text { yaitu kegiatan PKPR dan kegiatan penjaringan. Berdasarkan hasil wawancara } \\
\text { peran bidan terkait kesehatan sekolah yaitu pada kedua program tersebut. } \\
\text { Salah satu kegiatan PKPR yang dilakukan yaitu penyuluhan, beberapa } \\
\text { penyuluhan yang dilakukan meliputi penyuluhan tentang seks bebas, infeksi } \\
\text { menular seksual, HIV/AIDS, dan lain-lain. Berdasarakn hasil wawancara } \\
\text { puskesmas duren selain melaksanakan penyuluhan tentang kesehatan } \\
\text { reproduksi juga melaksanakan penyuluhan tentang penyakit kanker payudara } \\
\text { dan Sadari. }\end{array}$ \\
\hline 5 & $\begin{array}{l}\text { Puskesmas } \\
\text { Sumowono }\end{array}$ & $\begin{array}{l}\text { Peran bidan dalam kesehatan sekolah termasuk dalam upaya kesehatan } \\
\text { pengembangan. Beberapa program kegiatan kesehatan sekolah yang } \\
\text { dilaksanakan oleh puskesmas Sumowono yaitu kegiatan penjaringan dan } \\
\text { kegiatan PKPR. Beberapa kegiatan penjaringan yaitu pemeriksaan HB, } \\
\text { pemeriksaan gigi dan mulut untuk caries gigi, THT, dan pengukuran berat dan } \\
\text { tinggi badan. Adapun untuk kegiatan PKPR salah satu kegiatannya yaitu } \\
\text { penyuluhan, penyuluhan yang dilaksanakan meliputi penyuluhan tentang } \\
\text { kesehatan repoduksi remaja seperti bahaya seks bebas, penyakit menular } \\
\text { seksual, dan penyalahgunaan NAPZA dengan berkordinasi dengan polsek } \\
\text { setempat. Terkait penyuluhan tentang penyakit kanker payudara dan Sadari } \\
\text { belum dilaksanakan. }\end{array}$ \\
\hline
\end{tabular}

Sumber: Data Primer tahun 2018 
Berdasarkan hasil wawancara dengan kepala Puskesmas Pringapus, Ungaran, Kaliwungu, Duren dan Sumowono didapatkan hasil yaitu pada setiap puskesmas dalam memberikan pelayanan kesehatan mempunyai program pokok dan program pengembangan. Kegiatan pokok dan pengembangan puskesmas dilaksanakan sesuai kemampuan tenaga maupun kelengkapan fasilitasnya karena kegiatan pokok di setiap puskesmas dapat berbeda-beda. ${ }^{13}$

Bidan dalam menjalankan tugas dan kewenangannya diatur dalam Undang-undang nomor 36 Tahun 2014 tentang tenaga kesehatan pasal 44 ayat (1) yaitu :

"Bidan yang memberikan pelayanan kesehatan haruslah memiliki surat tanda registrasi (STR) yang merupakan bukti tertulis bahwa bidan sudah teregistrasi dan memiliki sertifikat kompetensi sesuai dengan ketentuan".

Semua tenaga kesehatan dalam menjalankan praktik harus sesuai kewenangan masingmasing tenaga kesehatan seperti yang dijelaskanpada Pasal 62 ayat (1) bahwa: "Tenaga Kesehatan dalam menjalankan praktik harus dilakukan sesuai dengan kewenangan yang didasarkan pada kompetensi yang dimilikinya".

Kewenangan berdasarkan kompetensi adalah kewenangan dalam melakukan pelayanan kesehatan secara mandiri berdasarkan ruang lingkup dan tingkat kompetensinya sedangkan pada bidan artinya bidan memiliki kewenangan untuk melakukan pelayanan kesehatan termasuk pelayanan kesehatan sekolah berdasarkan UU No 36 tahun 2009 tentang kesehatan dan Permenkes No 75 tahun 2014 tentangPuskesmas.

Hasil wawancara semua bidan telah melaksanakan pelayanan kesehatan sekolah melalui Program Penjaringan dan Program PKPR. Pada kegiatan Program Penjaringan hampir semua kegiatan yang dilaksanakan sama pada semua puskesmas yaitu meliputi: pemeriksaan fisik seperti: pengukuran tinggi dan berat badan, pemeriksaan gigi dan mulut, pemeriksaan Telinga, Hidung, dan Tenggorokan (THT), pemeriksaan mata, pemeriksaan HB dan pembagian obat penambah darah (tablet FE). Selanjutnya untuk program PKPR yang menjadi fokus kegiatannya yaitu untuk penyediaan pelayanan kesehatan remaja yang berkualitas, meningkatkan pengetahuan dan keterampilan remaja dalam pencegahan masalah kesehatan dan meningkatkan keterlibatan remaja dalam perencanaan, pelaksanaan dan evaluasi pelayanan kesehatan remaja. ${ }^{14}$

Hasil wawancara oleh peneliti mendapati salah satu responden merupakan salah satu siswi yang terserang kanker payudara. Informasi yang di peroleh saat wawancara responden mengatakan penyuluhan akan penyakit kanker payudara sangat penting diberikan oleh tenaga kesehatan dalam hal ini bidan. Responden mengatakan saat mengetahui ada benjolan pada payudara nya yaitu saat meraba payudaranya dan merasakan nyeri, akan tetapi responden awalnya merasa mungkin pengaruh menstruasi jadi payudara terasa tegang dan nyeri. ${ }^{15}$ Namun nyeri yang di dapatkan tidak hanya saat menstruasi tetapi juga saat tidak menstruasi. Responden mengatakan merasa cemas dan takut akan nyeri pada payudaranya, kemudian memutuskan untuk menceritakan kejadian tersebut pada orang tua.

Jadi melihat contoh kasus yang di alami oleh salah satu responden maka sudah seharusnya pada saat penyuluhan pihak puskesmas memasukkan materi penyuluhan tentang penyakit

\footnotetext{
${ }^{13}$ Hasil wawancara dengan 5 kepala Puskesmas Kabupaten Semarang, pada tanggal 11 September 2018

${ }^{14} \mathrm{Hasil}$ wawancara dengan bidan Puskesmas di Kabupaten Semarang, pada tanggal 9 September 2018.

${ }^{15}$ Hasil wawancara dengan Siswi SMA, pada tanggal 24 Agustus 2018.
} 
kanker payudara dan tindakan sadari pada remaja/peserta didik. Dari hasil wawancara semua responden mengatakan sangat mengharapkan adanya penyuluhan tentang penyakit kanker payudara dan tindakan sadari sebagai modal untuk pengetahuan mereka apalagi kanker payudara itu sendiri tidak hanya menyerang pasangan usia subur tetapi juga menyerang usia remaja.

Berdasarkan fakta tersebut maka puskesmas berupaya menyelenggaarakan pelayanan kesehatan dalam bentuk upaya promotif melalui penyuluhan. Hal tersebut sesuai dengan adanya beberapa temuan terhadap remaja terindikasi adanya benjolan pada payudara, hal tersebut yang mendasari pentingnya penyuluhan tentang kanker payudara dan tindakan Sadari pada siswa yang terkena kanker payudara beberapa bidan mengatakan akan memasukkan materi tentang kanker payudara dan Sadari pada saat melakukan penyuluhan. Bidan mengatakan untuk tindakan kanker payudara mereka fokus pada pasangan usia subur dengan pemeriksaan Sadanis dan pemeriksaan IVA. Beberapa pasien kanker payudara pasangan usia subur yang datang memeriksakan ke puskesmas sebagian besar sudah masuk dalam kategori stadium lanjut, jadi dengan mempertimbangkan pentingnya penyuluhan tentang penyadaran pemeriksaan payudara sendiri pada remaja diharapkan untuk tingkat pengobatannya bisa dilakukan sedini mungkin dalam stadium awal penyakit kanker payudara.

Berdasarkan uraian di atas dapat di ambil simpulan bahwa peran bidan dalam pelayanan kesehatan sekolah di Wilayah Kerja Puskesmas Kabupaten Semarang telah dilaksanakan melalui Program Penjaringan dan PKPR. Peran adalah menjalankan hak serta kewajiban sesuai dengan statusnya. peranan dapat diidentikkan sebagai kewajiban atau hak. Kewajiban merupakan peranan (role) imperatif karena tidak boleh tidak dilaksanakan, sedangkan hak adalah peranan (role) yang fakultatif sifatnya karena boleh tidak dilaksanakan.

Terkait pelaksanaan kedua peran tersebut seperti yang telah disebutkan di atas yaitu peran imperatif dan fakultatif puskesmas berupaya memberikan pelayanan kesehatan remaja sekolah sebagaimana di sebutkan dalam Undang-undang No 36 tahun 2009 tentang Kesehatan pada Pasal 79 ayat (1) disebutkan bahwa:

"Kesehatan sekolah diselenggarakan untuk meningkatkan kemampuan hidup sehat peserta didik dalam lingkungan hidup sehat sehingga peserta didik dapat belajar, tumbuh, dan berkembang secara harmonis dan setinggi-tingginya menjadi sumber daya manusia yang berkualitas".

Faktor Pendukung dan Penghambat Peran Bidan Puskesmas dalam Program Kesehatan Sekolah untuk Penyadaran Pemeriksaan Payudara Sendiri (Sadari) pada Siswi-siswi Sekolah Menengah Atas di Kabupaten Semarang

\section{Faktor Pendukung}

Faktor yang mendukung peran bidan dalam program kesehatan sekolah untuk Penyadaran Pemeriksaan Payudara Sendiri (Sadari) pada siswi-siswi sekolah menengah atas yaitu ketersediaan fasilitas kesehatan yang mempengaruhi pelayanan kesehatan.

Faktor lain yang menjadi pendukung yaitu adanya kerjasama antara Puskesmas dengan pihak sekolah melalui wadah UKS. Puskesmas dan usaha kesehatan masyarakat yang dijalankan di sekolah-sekolah dengan anak didik serta lingkungan sekolahnya sebagai sasaran utama. UKS merupakan perpaduan antara dua upaya dasar, yaitu upaya 
pendidikan dan upaya kesehatan yang pada gilirannya diharapkan dapat dijadikan usaha yang dapat meningkatkan kesehatan anak usia sekolah setiap jalur, jenis, dan jenjang kesehatan. Dengan kata lain, UKS merupakan wadah untuk meningkatkan kemampuan hidup sehat dan derajat kesehatan peserta didik sedini mungkin.

\section{Faktor Penghambat}

Faktor yang menghambat peran bidan dalam program kesehatan sekolah untuk penyadaran pemeriksaan payudara sendiri (Sadari) pada siswi-siswi sekolah menengah atas yaitu ketersediaan Sumber Daya Kesehatan. Berdasarkan WHO, sumber daya manusia kesehatan merupakan semua orang yang kegiatan pokoknya ditujukan untuk meningkatkan suatu pelayanan kesehatan. Mereka terdiri atas orang-orang yang memberikan pelayanan kesehatan diantaranya dokter, bidan, perawat, apoteker serta tenaga dukungan seperti bagian keuangan, dan sopir ambulans.

Faktor penghambat lainnya yaitu belum adanya peraturan perundang-undangan yang mengatur, sehingga pelaksanaan program tersebut belum berjalan dengan optimal. Dengan adanya peraturan perundang-undangan maka akan menjadi acuan atau pedoman dalam melaksanakan tugas sesuai dengan kewenangan dan tanggung jawab tenaga kesehatan. Hasil wawancara oleh bidan mengatakan bahwa belum terprogramnya periksa payudara sendiri merupakan salah satu faktor penghambat sehingga pelaksanaan penyuluhan tidak terlaksana secara menyeluruh karena bidan berfokus pada penyuluhan yang berkaitan tentang kesehatan reproduksi. Sehingga untuk mewujudkan terlaksananya penyuluhan tersebut harus maka program tersebut harus menjadi salah satu program wajib di puskesmas. Beberapa faktor penghambat lainnya yaitu ketersediaan jumlah tenaga kesehatan sangat berpengaruh terhadap penyelenggaraan suatu program kesehatan yang dilaksanakan oleh Puskesmas. ${ }^{16}$ Selain itu faktor lain yang mempengaruhi yaitu keuangan/dana, bidan mengatakan karena minimnya anggaran untuk pelaksanaan program sehingga tidak optimalnya program tersebut.

Jadi faktor komunikasi sangat mempengaruhi dalam menjalin hubungan dengan siswasiswa agar apa yang disampaikan bisa diterima dengan baik dan juga dapat diterapkan oleh siswa-siswi dalam kehidupan sehari-hari. Konseling yang di berikan terhadap remaja bertujuan untuk memberikan pemahaman serta upaya penyesuaian terhadap perubahan fisik, sehingga pelaksanaan konseling untuk remaja dengan metode pendekatan kelompok bidan untuk menjalin kominikasi secara terbuka dengan menyampaikan informasi yang belum diketahui remaja.

Berdasarkan penjelasan di atas dapat ditarik simpulan bahwa selain faktor komunikasi, ketersedian sumber daya kesehatan dalam hal ini tenaga kesehatan juga sangat mempengaruhi terhadap penyelenggaraan suatu program kesehatan yang dilaksanakan oleh Puskesmas. Negara mempunyai peranan lewat pemerintah untuk menyusun peraturan dalam memberikan perlindungan hukum terhadap setiap anggota masyarakat. Peraturan yang dikeluarkan oleh pemerintah salah satunya mengatur tentang kesehatan agar terciptanya pelayanan kesehatan yang optimal dan nondiskriminatif dan mewujudkan hak masyarakat dalam mendapatkan pelayanan kesehatan yang baik.

\footnotetext{
${ }^{16} \mathrm{Hasil}$ wawancara dengan bidan puskesmas Kabupaten Semarang, pada tanggal 10 September 2018.
} 


\section{PENUTUP \\ KESIMPULAN}

1. Puskesmas dalam sistem kesehatan nasional merupakan pelayanan kesehatan tingkat pertama yang bertanggungjawab menyelenggarakan upaya kesehatan perorangan dan upaya kesehatan masyarakat. Dimana keduanya jika ditinjau dari upaya kesehatan tersebut dikelompokkan menjadi dua yaitu upaya kesehatan wajib dan upaya kesehatan pengembangan. Pada Upaya Kesehatan pengembangan salah satu kegiatan yang dilaksanakan yaitu program kesehatan sekolah. Dalam pelaksanaan program sekolah kegiatan yang dilaksanakan yaitu kegiatan Penjaringan dan PKPR. Untuk kegiatan Penjaringan dan PKPR semua puskemas melaksanakan kegiatan tersebut. Berdasarkan hal tersebut bidan telah melaksanakan perannya sebagai peneliti yaitu dengan memberikan pendidikan dan penyuluhan kesehatan. Jadi implementasi Pasal 79 ayat (1) tentang kesehatan sekolah pada siswi-siswi sekolah menengah atastelah dilaksanakan oleh bidan puskesmas melalui program penjaringan dan program PKPR.

2. Peran bidan dalam pelaksanaan program kesehatan sekolah di beberapa Puskesmas di Kabupaten yaitu bidan sudah melaksanakan perannya sesuai dengan kewenangannya berdasarkan UU No 36 tahun 2009 tentang Kesehatan Pasal 79 ayat (1) dan Permenkes No 75 tahun 2014 tentang Puskesmas pasal 36 ayat (1), melalui Program Penjaringan dan PKPR, akan tetapi pelaksanaan penyuluhan terkait penyadaran pemeriksaan payudara sendiri terhadap remaja/peserta didik belum terlaksana secara menyeluruh, karena pemeriksaan payudara sendiri tidak menjadi program wajib di puskesmas, sehingga pelaksanaan penyuluhan belum maksimal. Puskesmas yang sudah melaksanakan hanya satu dari lima puskesmas yang menjadi tempat penelitian. Keempat Puskesmas lainnya lebih berfokus pada program sadanis (periksa payudara klinis) pada Wanita Usia Subur (WUS).

3. Faktor pendukung dalam peran bidan puskesmas dalam program kesehatan sekolah untuk penyadaran pemeriksaan payudara sendiri (Sadari) pada siswi-siswi Sekolah Menengah Atas yaitu ketersediaan fasilitas pelayanan kesehatan meliputi: ruang bimbingan konseling remaja di puskesmas, ruang UKS, serta adanya kerja sama antara puskesmas dan pihak sekolah terkait pelaksanaan program kesehatan sekolah melalui koordinasi guru pembina UKS dengan bimbingan teknis dan pengawas puskesmas setempat.

Adapun faktor penghambat dalam peran bidan puskesmas dalam program kesehatan sekolah untuk penyadaran pemeriksaan payudara sendiri (Sadari) pada siswi-siswi Sekolah Menengah Atas yaitu Ketersediaan Sumber Daya Kesehatan (SDM) Ketersediaan jumlah tenaga kesehatan sangat berpengaruh terhadap penyelenggaraan suatu program kesehatan yang dilaksanakan oleh puskesmas. belum adanya peraturan perundang-undangan yang mengatur, sehingga pelaksanaan program tersebut belum berjalan dengan optimal. Dengan adanya peraturan perundang-undangan akan memberikan kepastian hukum bagi tenaga kesehatan yang menyelenggarakan program tersebut dan juga akan menjadi acuan atau pedoman dalam melaksanakan tugas sesuai dengan kewenangan dan tanggung jawab tenaga kesehatan. Belum terprogramnya periksa payudara sendiri (Sadari) merupakan salah satu faktor penghambat sehingga pelaksanaan penyuluhan tidak terlaksana secara menyeluruh karena bidan berfokus pada penyuluhan yang berkaitan tentang kesehatan reproduksi. Sehingga untuk mewujudkan terlaksananya penyuluhan tersebut harus maka program tersebut harus 
menjadi salah satu program wajib di puskesmas. Faktor keuangan/dana, minimnya anggaran yang kemudian dari dana tersebut masih harus dibagi ke beberapa program lainnya yang dilaksanakan oleh puskesmas. Faktor lainnya yaitu faktor komunikasi, hal tersebut sangat mempengaruhi dalam menjalin hubungan dengan siswa-siswa agar apa yang disampaikan bisa diterima dengan baik dan juga dapat diterapkan oleh siswa-siswi dalam kehidupan sehari-hari.

\section{SARAN}

1. Bagi Tenaga Kesehatan (Bidan)

Tenaga kesehatan yang terlibat (bidan) sebagai tenaga kesehatan yang ada di masyarakat harus senantiasa mengembangkan dan meningkatkan ilmu pengetahuan dan kemampuan dalam melaksanakan kewenangannya sebagai seorang bidan. Bidan dalam hal ini sebagai orang yang melakukan penyuluhan kesehatan yang meliputi pendidikan kesehatan terkait kesehatan reproduksi tetapi juga melaksanakan penyuluhan tentang pentingnya SADARI. Pendidikan kesehatan terkait periksa payudara sendiri akan menambah pengetahuan wanita terkait periksa payudaranya sendiri sehingga status kesehatan perempuan meningkat.

Bidan harus mampu memberikan pelayanan kesehatan yang bermutu dan komprehensif (berkesinambungan, terpadu, dan paripurna), yang mencakup upaya promotif, preventif, kuratif dan rehabilitatif dalam upaya pemeriksaan payudara sendiri (Sadari) mencapai terwujudnya paradigma sehat.

2. Bagi Puskesmas

Puskesmas sebagai salah satu fasilitas pelayanan kesehatan tingkat pertama harus memberikan pelayanan yang optimal dan berkaulitas untuk mewujudkan derajat kesehatan masyarakat yang setinggi-tingginya. Manajemen sumber daya manusia harus di fungsikan sesuai tugas dan wewenangnya dalam memegang program kesehatan.

\section{Bagi Sekolah}

Bagi sekolah agar lebih sering melakukan seminar tentang bagaimana membina perilaku hidup sehat dan dapat mengoptimalkan fungsi UKS dalam pelayanan kesehatan sekolah. Kepada seluruh siswa khuusnya pada masa usia sekolah dapat meningkatkan dan mengembangkan budaya gaya hidup sehat di dalam lingkungan sekolah dan lingkungan masyarakat pada umumnya.

4. Bagi Kabupaten Semarang

Bagi pihak pemerintah daerah mengenai cakupan skrining kesehatan terutama terkait skrining kanker payudara melalui pemeriksaan payudara klinis (SADANIS), diharapkan pemerintah daerah bisa memasukkan program pemeriksaan payudara sendiri (SADARI) menjadi salah satu program skrining yang diselenggarakan oleh Puskesmas untuk peserta didik/remaja melihat fakta pentingnya pendidikan kesehatan untuk mewujudkan remaja sehat dan berkualitas. 


\section{DAFTAR PUSTAKA}

Alamsyah Dedi, 2012, Manajemen Pelayanan Kesehatan. Yogyakarta: Nuha Medika.

Bambang Sunggono, 2007, Metode Penelitian Hukum, Jakarta Rajagrafindo Persada.

Ghony Djunaidi dan Fauzan Almanshur, 2014, Metode Penelitian Kualitatif, Yogyakarta: ArRuzz Media.

Intan Kumalasari dan Iwan Andhyantoro, , 2013, Kesehatan Reproduksi untuk Mahasiswa Kebidanan dan Keperawatan, Jakarta: Salemba Medika.

Muchtar Masrudi, 2014, Bidan dan Dinamika Hukum Kesehatan Reproduksi di Indonesia, Yogyakarta: Aswaja Pressindo.

Notoatmodjo Soekidjo, 2010, Etika dan Hukum Kesehatan, Jakarta: Rineka Cipta.

Ronny Hanitijo S, 1990, Metodologi Penelitian Hukum dan Jurimetri, Jakarta: Ghalia Indonesia.

\section{JURNAL}

Rahmatari Aida, Anggapan Kesehatan Yang Dirasakan Wanita Usia Subur Dalam Memeriksakan Payudara Sejak Dini, Universitas Airlangga. Volume 2, No 3, September 2014. Hal309-320. https://e-journal.unair.ac.id/JBE/article/viewFile/1298/1057diakses tanggal 23 maret 2018 jam 20.15 WIB.

\section{PERUNDANG-UNDANGAN}

Undang-Undang Dasar Negara Republik Indonesia tahun 1945

http://peraturan.go.id/uud/nomor-tahun-1945.html

Undang-Undang Nomor 36 tahun 2009 Tentang Kesehatan

http://peraturan.go.id/uu/nomor-36-tahun-2009.html

Keputusan Menteri Kesehatan Nomor 796/MENKES/SK/VII/2010 tentang Pedoman Teknis Pengendalian Kanker Payudara dan Kanker Rahim

http://hukor.kemkes.go.id/uploads/produk_hukum/PMK_No._34_ttg_Penanggulangan_Kan ker_Payudara_dan_Leher_Rahim_.pdf

Peraturan Menteri Kesehatan Nomor 34 tahun 2015 tentang Penanggulangan Kanker Payudara dan Kanker Leher Rahim

http://ditjenpp.kemenkumham.go.id/arsip/bn/2015/bn706-2015.pdf 
SOEPRA Jurnal Hukum Kesehatan

ISSN:2548-818X (media online) Vol. 5 | No. 1 | Juni 2019

Peraturan Menteri Kesehatan Republik Indonesia Nomor 39 Tahun 2016 tentang Pedoman Penyelenggaraan Program Indonesia Sehat Dengan Pendekatan Keluarga

http://www.depkes.go.id/resources/download/lain/PMK_No.39_ttg_PIS_PK.pdf

Peraturan Menteri Kesehatan Republik Indonesia Nomor 43 Tahun 2016 tentang Standar Pelayanan Minimal Bidang Kesehatan

https://jisn.go.id/storage/app/uploads/public/58d/486/f01/58d486fo10a3fo67108647.pdf

Peraturan Menteri Kesehatan Nomor 28 tahun 2017 tentang Izin dan Penyelenggaraan Praktik Bidan.

http://www.ibi.or.id/media/PMK\%20No.\%2028\%20ttg\%20lzin\%20dan\%20Penyelenggaraan\%20 Praktik\%20Bidan.pdf 